\title{
PRIEMONIŲ, SKIRTU NEGALIĄ TURINČIŲ VAIKŲ IR JŲ TĖVŲ PSICHOSOCIALINĖS SVEIKATOS IR SOCIALINĖS IৃTRAUKTIES GERINIMUI, POREIKIS IR NAUDA
}

\author{
Viktorija Piščalkienė, Lijana Navickienė \\ Kauno kolegijos Medicinos fakultetas
}

Raktažodžiai: negalią turintys vaikai, socialinè integracija, psichosocialinè sveikata.

\begin{abstract}
Santrauka
Vaiko negale yra išbandymas visiems šeimos nariams. Vakarų šalyse socialinès, medicininès ir edukologinès pagalbos negalei sistema gyvuoja jau ne vieną dešimtmeti. Lietuvoje sukurta reikiama teisinè bazè, tačiau tokio pobūdžio pagalbos tradicijos tik formuojasi. Vienas veiksmingiausių būdų, gerinantis tèvų, artimujų fizinę ir emocinę sveikatą, padedantis mažinti nuovargi, stresą yra konsultavimas ir psichosocialinio pobūdžio parama. Vienas iš efektyviausių metodų, leidžiančiu pasiekti emocinès ir fizinès pusiausvyros, yra panašaus pobūdžio gyvenimo išbandymus patiriančių asmenų savitarpio pagalbos grupès.

2018-2019 m. Kauno kolegija kartu su Kauno rajono socialinių paslaugų centru įgyvendino Visuomenès sveikatos stiprinimo fondo finansuotą projektą „Vaikų, turinčių kompleksinę negalią, sveikatos stiprinimas fiziniu ir psichosocialiniu požiūriu“. Projektu siekta prisidèti prie negalią turinčių vaikų ir jų artimujų fizinès ir emocinès sveikatos gerinimo, socialinès ịtraukties didinimo. Projekto veiklos rūšys aprèpé neigalių vaikų tėvų mokymą ir konsultavimą fizinio aktyvumo stiprinimo, sveikatos priežiūros klausimais, edukacines keleto dienų stovyklas, artimųų savitarpio pagalbos grupių organizavimą. Projekto tikslinè grupè - negalią turintys vaikai $(\mathrm{N}=60)$ ir jų tėvai, broliai ar seserys $(\mathrm{N}=120)$. Igyvendinant projektą, remtasi socialine paradigma „Kokie yra vaiko sveikatos šaltiniai?“" „Kaip juos stiprinti?“ Vaiko sunkumai buvo sprendžiami orientuojantis i jo galias, gebejjimus, panaudojant ne tik jo, bet ir ji supančios aplinkos išteklius.

Tyrimu siekta atskleisti tėvų nuomonę apie projekto veiklos rūšių bei taikytų priemonių poreikị ir naudą
\end{abstract}

neigaliems vaikams ir patiems tèvams. Tyrime dalyvavo 54 tèvai, auginantys negalią turinčius vaikus. Tyrimo tikslui pasiekti vykdyta apklausa raštu. Klausimai suskirstyti ị uždaro ir atviro tipo (kokybinius). Tyrimo rezultatai atskleide palankų visų projekto veiklos rūšių vertinimą. Tẻvai nurodé, kad dalyvaudami projekte jie ịgijo naudingų žinių vaikų burnos higienos, mitybos, pirmosios medicinos pagalbos, lytinio brendimo ir kt. klausimais, patobulino gastrostomų, tracheostomų priežiūros ịgūdžius, išmoko masažo pagrindų. Tẻvai taip pat įžvelgẻ psichologinę ir socialinę dalyvavimo projekte naudą. Jie teigè pagerinę emocinę sveikatą bei patobulinę bendravimo su vaikais ir kitais šeimos nariais ịgūdžius.

\section{Ivadas}

Lietuvos Respublikos socialinès apsaugos ir darbo ministerijos duomenimis [7], $2018 \mathrm{~m}$. pabaigoje Lietuvoje buvo 14,8 tūkst. neigalių vaikų iki 18 metų. Šis skaičius sudarè 2,9 procentus nuo bendrojo vaikų skaičiaus (503 tūkst.) šalyje.

Šeimos, auginančios neiggalius vaikus, patiria specifinių problemų. Tokiose šeimose dažnesnis negatyvus psichosocialinis klimatas: stresinès situacijos, konfliktai, tèvų nusivylimas savo vaidmeniu, žinių apie vaikų su tam tikra negalia priežiūrą ir ugdymą trūkumas. Socialinè atskirtis yra viena iš pagrindinių neigalius vaikus auginančių šeimų problemų, nulemta stigmatizacijos, neigiamo aplinkinių požiūrio, smerkimo, gailesčio ir panašių visuomenès reakcijų.

2006 m. priimtoje Jungtinių Tautų neiggaliujjų teisių konvencijoje (toliau - Konvencija) įtvirtintas tikslas - skatinti ir užtikrinti asmenų, turinčių negalią, visapusišką ir lygiateisị naudojimąsi visomis žmogaus teisèmis ir laisvèmis, skatinti pagarbą šiu asmenų prigimtiniam orumui. Šio tikslo siekimo priemonèmis ugdomas naujas požiūris į negalią, kviečiantis užkirsti kelią diskriminacijai ir sudaryti sąlygas neiggaliesiems aktyviai dalyvauti švietimo, kultūros, sveikatos, darbo rinkos ir kituose visuomenés sektoriuose [12]. 
Ratifikavusi Konvenciją 2010 m., Lietuva ịsipareigojo užtikrinti negalią turinčių asmenų lygias teises ir galimybes visuomenejje, sukurti ir užtikrinti asmenų su negalia visaverčio socialinio dalyvavimo prielaidas. Negalią turinčių asmenų, tarp jų ir vaikų, teisès ir galimybès apibrèžiamos ìvairiuose Lietuvos teisès aktuose ir dokumentuose, atliepiančiuose pagrindines Konvencijos nuostatas: tai Neigaliuju socialinès integracijos ịstatymas (1991) [6], Valstybinè šeimos politikos koncepcija (2008) [3], Vaiko teisių apsaugos pagrindu įstatymas (1996) [10], Specialiojo ugdymo ịstatymas (1998) [8], Lygiu galimybių įstatymas (2003) [5], Vaiko gerovès valstybės politikos koncepcija (2003) [2], Švietimo i̊statymas (2013) [9], Nacionalinè neigaliujų socialinès integracijos 2013-2019 m. programa (2012) [1]. Pavyzdžiui, $2018 \mathrm{~m}$. liepos $1 \mathrm{~d}$. ịsigaliojusiame Vaiko teisių apsaugos pagrindu įstatymo 19 str. nurodyta, kad vaikai su negalia turi lygias teises su kitais vaikais igyvendinti visas žmogaus teises ir pagrindines laisves, jiems pagal ịstatymą užtikrinama tinkama pagalba, teisè ị švietimą ir prieinamumą [10].

Neiggalių asmenų, tarp jų ir vaikų, socialinès integracijos, medicininès, edukacinès ir psichosocialinio pobūdžio pagalbos teisinè bazè pakankama, siekiant užtikrinti visavertị šių asmenų funkcionavimą visuomenèje, tačiau įvairių tyrimų ir studijų rezultatai išryškina akivaizdų neatitikimą tarp valstybiniuose dokumentuose deklaruojamų principu bei jų igyvendinimo galimybių ir realios situacijos. Neretai vaikai su negalia patiria diskriminaciją, ivvairių sunkumų švietimo, sveikatos apsaugos, socialinès apsaugos, sporto ir kultūros srityse [11]. Pavyzdžiui, apklausos rodo, kad kas antram Lietuvos pedagogui būdingos segregacinès nuostatos ịvairių sutrikimų turinčių vaikų atžvilgiu, t.y. siekis juos ugdyti specialiose mokyklose, klasėse ar namuose, apribojant sąveiką su bendraamžiais bei didinant socialinę atskirti [4]. Pasigendama priemonių, kurios padètų šeimos nariams suprasti negalią turintị vaiką ir jo poreikius bei gerintu negalios paliestų šeimu psichosocialinès sveikatos stiprinimo igūdžius $[11,12]$. Trūksta kvalifikuotos pagalbos šeimoms, kuriose auga vaikai su negalia, atsižvelgiant ị kiekvienos negalios sąlygotą specifiką [12], pvz. burnos sveikatos priežiūra, masažai, tracheostomų, gastrostomų priežiūra, lytinis brendimas ir pan.

Minèti trūkumai rodo edukacinès, konsultacinès, socialinès ir psichosocialinio pobūdžio pagalbos šeimoms, auginančioms vaikus su negalia, poreikị, siekiant gerinti šiu vaikų ir jų šeimų socioemocinę sveikatą, gilinti su negalia susijusias žinias, skatinti negalios paliestų šeimų socialini dalyvavimą. Ši poreikị atliepia 2018-2019 m. Kauno kolegijos ir Kauno rajono socialinių paslaugų centro igyvendintas Valstybinio visuomenès sveikatos stiprinimo fondo finansuotas projektas „Vaikų, turinčių kompleksinę negalią, sveikatos stiprinimas fiziniu ir psichosocialiniu požiūriu“. Projektu siekta tarpdiciplininèmis prieigomis ir tikslingais, patraukliais bei saugiais metodais ir formomis prisidèti prie negalią turinčių vaikų ir jų artimujjų fizinès ir emocinès sveikatos gerinimo, socialinès įtraukties didinimo. Projekto veikla apėmé tèvų mokymą ir konsultavimą vaikų, turinčių negalią, fizinio aktyvumo stiprinimo, sveikatos priežiūros klausimais, edukacines kelių dienų stovyklas, artimųų savitarpio pagalbos grupių organizavimą.

Tyrimo tikslas - atskleisti priemonių, skirtų negalią turinčių vaikų ir jų tèvų psichosocialinès sveikatos ir socialinès ịtraukties gerinimui, poreikị ir naudą.

\section{Tyrimo objektas ir metodai}

2018-2019 metais Kauno kolegija, kartu su Kauno rajono socialinių paslaugų centru, igyvendino projektą „Vaikų, turinčių kompleksinę negalią, sveikatos stiprinimas fiziniu ir psichosocialiniu požiūriu“". Trumpas šio projekto pavadinimas - „(ne)GALIU“. Projektą finansavo Valstybinis visuomenès sveikatos stiprinimo fondas.

Projekto tikslas - stiprinti vaikų, turinčių kompleksinę negalią, sveikatą fiziniu ir psichosocialiniu požiūriu. Siekiant šio tikslo, projekte organizuota ir igyvendinta trijų rūšių veikla: edukacinès sveikatinimo programos (2 dienų trukmès edukacinès stovyklos), skirtos vaikų su negalia ir jų artimųų fizinès ir emocinès sveikatos stiprinimui; tèvų paramos ir savitarpio pagalbos grupès, kurių pagalba siekta gerinti tėvų, auginančių vaikus su negalia, emocinę, psichosocialinę kompetenciją bei konsultaciniai seminarai vaikų su negalia fizinès sveikatos išsaugojimo ir stiprinimo klausimais. Metu trukmès projekto veikla pasiekè 62 Kauno regiono neigalius vaikus ir 120 jų tèvų. Projekte dalyvavo 22 vaikai, kuriems buvo nustatytas autizmo spektro sutrikimas, 15 - cerebrinis paralyžius, 9 - Dauno sindromas, 7 - retos genetinès ligos, 6 - galvos smegenų susirgimai, 3 - protinè negalia. Projekte dalyvavusių vaikų amžius buvo nuo 1,5 iki 17 metų.

Šiuo tyrimu siekta įvertinti projekto veiklos rūšiu poreiki ir naudą. Siekiant tyrimo tikslo, vykdyta tėvų, auginančių vaiką su negalia ir įsitraukusių i projekto veiklą, apklausa raštu, apimanti uždaro ir atviro tipo (kokybinius) klausimus. Tyrime dalyvavo 54 negalią turinčių vaikų tèvai.

\section{Tyrimo rezultatai}

Dauguma ị projekto veiklą ir šį tyrimą įsitraukusių tėvų dalyvavo edukacinèse sveikatinimo programose (edukacinèse stovyklose) bei konsultaciniuose seminaruose vaikų su negalia fizinès sveikatos išsaugojimo ir stiprinimo klausimais (1 pav.). Projekto dalyviams (negalią turintiems vaikams ir jų šeimos nariams - tèvams, broliams, seserims) buvo organizuotos trys kartotinio tipo (balandžio, gegužès, bir- 
želio mėnesiais) savaitgalio edukacinès stovyklos Birštono „Eglès“ sanatorijoje. Visi edukacinèse stovyklose dalyvavę tėvai nurodè, kad dalyvavimas šioje veikloje buvo naudingas.

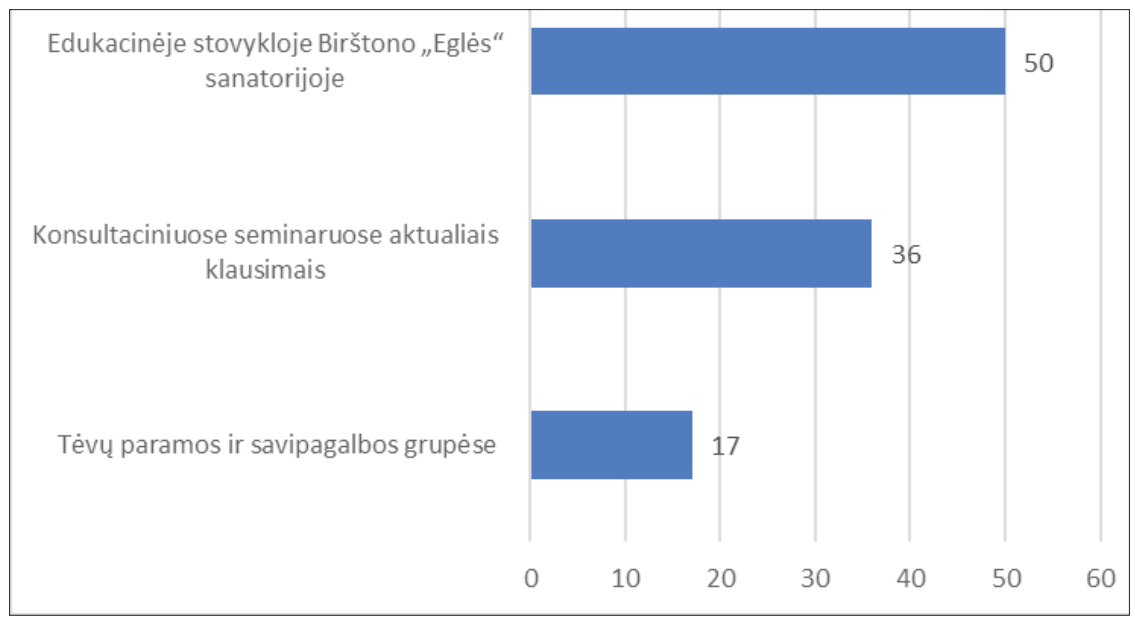

1 pav. Projekto veiklos rūšys, kuriose dalyvavo vaikus su negalia auginantys tèvai $(\mathrm{N}=54)$.

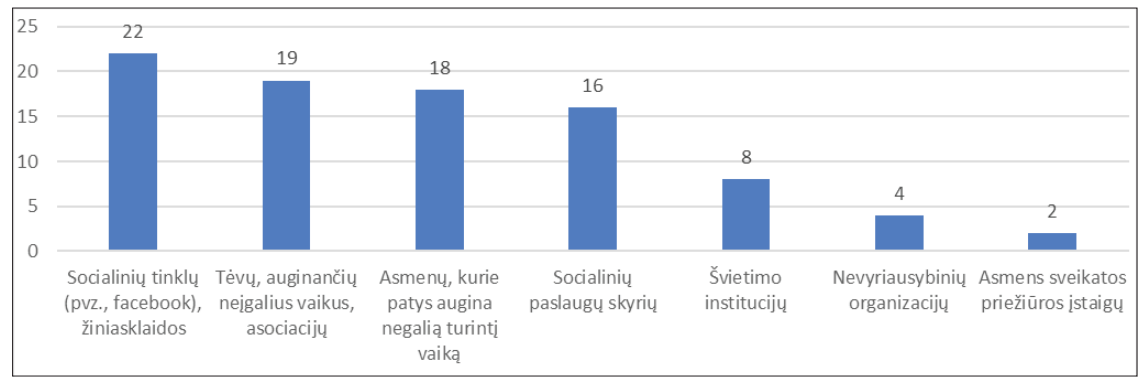

2 pav. Informacijos apie projektą ir jo veiklos rūšis, kanalai $(\mathrm{N}=54)$.

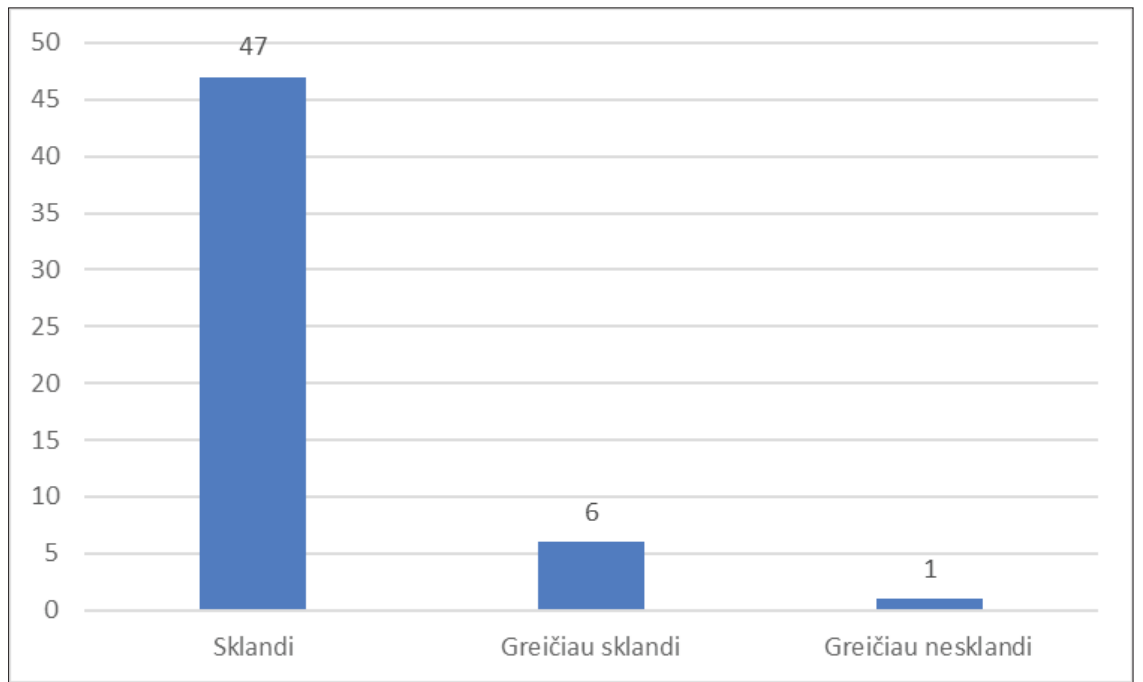

3 pav. Projekto organizatorių ir negalią turinčių vaikų tėvų komunikacijos vertinimas $(\mathrm{N}=54)$.
Konsultacinių seminarų metu tèvai turejo galimybę gauti ne tik teorinių žinių, bet ir praktinių igūdžių aktualiais neigalių vaikų auginimo ir priežiūros klausimais. Konsultaciniai seminarai apèmé mitybos, burnos priežiūros, lytinio brendimo, pirmosios medicinos pagalbos, tracheostomų, gastrostomu priežiūros klausimus, tèvai turèjo galimybę ịgti masažo pagrindų, pasigaminti natūralios kosmetikos. 34 iš 36 veikloje dalyvavusių tèvų teigè, kad jiems šie mokymai buvo labai naudingi.

Tèvų paramos ir savipagalbos grupių užsièmimuose dalyvavo 17 tėvų, auginančių negalią turinčius vaikus. Visi tèvai, dalyvavę šioje veikloje, pripažino tokių užsièmimų poreikị ir naudą.

Apie projektą tèvai, auginantys vaikus su negalia, sužinojo iš įvairių informacijos šaltinių (2 pav.). Populiariausias - socialiniai tinklai (informaciją rado Facebook paskyroje ar žiniasklaidoje). Nemažai tèvų informaciją apie projektą gavo iš ịvairių asociacijų, kitų tėvų, auginančių negalią turinčius vaikus, asociacijų, socialinių paslaugų skyrių.

Projekto efektyvumui labai svarbi organizatorių ir dalyvių komunikacija, todèl svarbu buvo sužinoti, kaip tèvai, auginantys neigalius vaikus, vertina šį procesą.

Apklausoje dalyvavę tèvai komunikaciją, kurią padejo užtikrinti projekto organizatoriai (3 pav.), vertino teigiamai. 47 respondentai pritare teiginiui, kad komunikacija buvo „sklandi“, 6 manè, kad „greičiau sklandi“, o 1 nurodè, jog „greičiau nesklandi“". Nebuvo nei vieno respondento, kuris būtų teigęs, kad komunikacija projekte buvo „,nesklandi“.

Siekiant detaliau sužinoti apie projekto veiklos rūšiu poreikị ir naudą, tevams buvo skirtas atviras klausimas, kuriame prašyta parašyti savo nuomonę, vertinimus apie pro- 
jektą. Atsakymų turinio analizė (content analysis) atskleidè, jog savo pasisakymuose tèvai labai šiltai, atvirai kalba apie jų vaikams ir jiems patiems suteiktą projekto naudą (1 lentelè).

Tẻvai džiaugèsi vykdytu projektu ir teigiamai vertino personalo darbą $(\mathrm{N}=38)$, pažymėdami nuoširdų, šiltą, draugišką personalo bendravimą su jais, patraukliai paruoštas edukacines programas, tinkamai parinktą savaitgalio edukacinių stovyklų organizavimo vietą, vadovavimą projektui ir pan. Pozityvų projekto veiklos ir personalo darbo vertinimą atspindi šie atsakymai:

„Organizatoriai paruošè nuostabias edukacines programas. Ačiū visai komandai“. „Patiko pats buvimas sanatorijoje, nes savo léšomis to sau negalime, geros sąlygos sanatorijoje“. „Stovykla puikiai organizuota“. „Betarpiškas bendravimas ir puikios gyvenimo sąlygos“. „Labai patiko organizatorių komanda - visada buvo šalia, labai malonūs ir paslaugūs“. „Labai patiko šiltas ir nuoširdus bendravimas tiek su vadove, tiek su dèstytojais, savanoriais“. „Projekto vadovei - 100 balų! Visiems sèkmès ir tikiuosi dar susitiksime kitose jūsų organizuojamose veiklose“. „Norime labai padėkoti už galimybę dalyvauti tokiame projekte, už parodytą dèmesị ir jautrumą visos komandos. Esate visi nuostabūs. Sèkmès jums jūsų darbuose ir toliau išlikti tokiais šauniais“. „Labai patiko nuoširdumas seminarų metu ir geros atmosferos išlaikymas tèvų, lektorių ir projekto vadovès bendravime“.

Tèvai akcentavo gerai organizuotą vaikų užimtumą stovyklų metu $(\mathrm{N}=27)$, prie kurio daug prisidejo savanoriai Kauno kolegijos Medicinos fakulteto dėstytojai, jų vaikai (vaikų, turinčių negalią bendraamžiai), Kauno rajono socialinių paslaugų centro darbuotojai, studentai, vaikų, turinčių negalią, broliai ir seserys.

„Smagu buvo vaikams stovyklos metu“. „Labai patiko apsilankymas baseine, tiek vaikų, tiek tèvų užimtumas“.
1 lentelè. Projekto nauda tėvų požiūriu (kokybinè prieiga).

\begin{tabular}{|c|c|c|}
\hline Kategorija & $\mathbf{N}$ & Autentiški pavyzdžiai \\
\hline $\begin{array}{l}\text { Pozityvus } \\
\text { projekto veiklos } \\
\text { ir personalo } \\
\text { vertinimas }\end{array}$ & 38 & 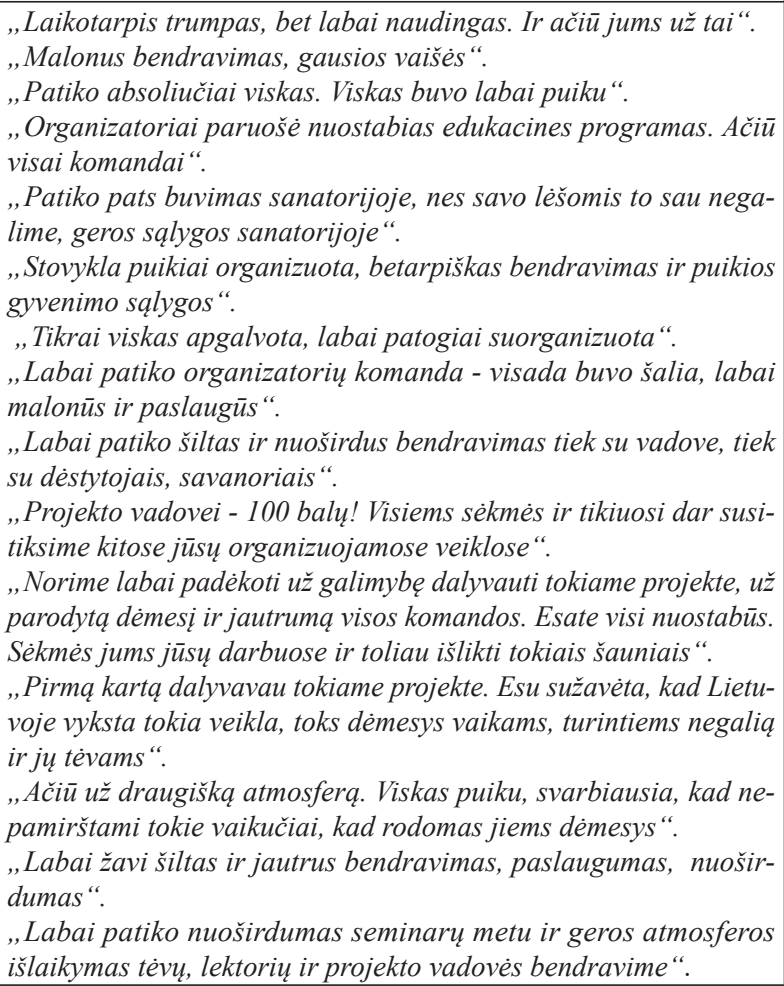 \\
\hline $\begin{array}{l}\text { Gerai organi- } \\
\text { zuotas vaikų } \\
\text { užimtumas } \\
\text { ir prasminga } \\
\text { veikla }\end{array}$ & 27 & 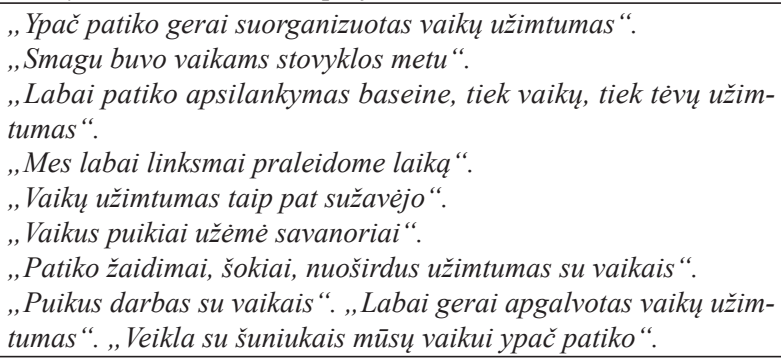 \\
\hline $\begin{array}{l}\text { Profesionalūs } \\
\text { specialistų } \\
\text { mokymai ir } \\
\text { konsultacijos }\end{array}$ & 25 & 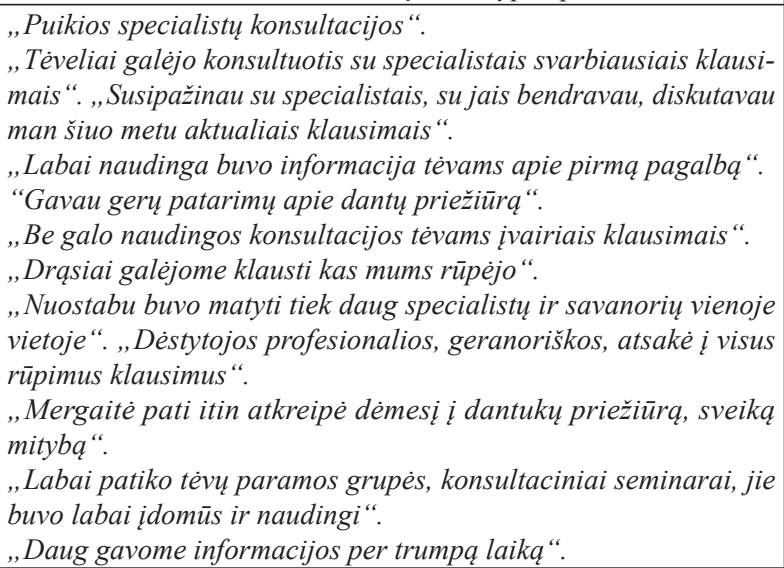 \\
\hline
\end{tabular}

Lentelès tęsinys kitame puslapyje. 
„Mes labai linksmai praleidome laiką“. „Vaikų užimtumas taip pat sužavejjo“. „Vaikus puikiai užèmé savanoriai“. „Patiko žaidimai, šokiai, nuoširdus užimtumas su vaikais“. „Puikus darbas su vaikais“. „Labai gerai apgalvotas vaiku užimtumas“. „Veikla su šuniukais mūsų vaikui ypač patiko“.

Apklausoje dalyvavę tèveliai labai palankiai atsiliepè apie mokymus ir konsultacijas, kurios, pasak jų, buvo profesionalios ( $\mathrm{N}=25)$.

„Tėveliai galèjo konsultuotis su specialistais svarbiausiais klausimais“. „Susipažinau su specialistais, su jais bendravau, diskutavau man šiuo metu aktualiais klausimais“. „Labai naudinga buvo informacija tėvams apie pirmą pagalbą“. „Gavau gerų patarimų apie dantų priežiūrą““. „Be galo naudingos konsultacijos tèvams ịvairiais klausimais“. „Nuostabu buvo matyti tiek daug specialistų ir savanorių vienoje vietoje“. „Dėstytojos profesionalios, geranoriškos, atsakè ị visus rūpimus klausimus“. „Labai patiko tėvų paramos grupès, konsultaciniai seminarai, jie buvo labai įdomūs ir naudingi“".

Iš socialinio dalyvavimo perspektyvos kaip projekto privalumus tėvai išskyrè galimybę atitrūkti nuo kasdienybès $(\mathrm{N}=15)$ ir bendradarbiavimo tinklų tarp tėvų, auginančių neiggalius vaikus, plètojimą $(\mathrm{N}=14)$. Tai iliustruoja šie jų atsiliepimai:

Lentelès pabaiga.

\begin{tabular}{|c|c|c|}
\hline $\begin{array}{l}\text { Tẻvams } \\
\text { galimybė } \\
\text { atsipalaiduoti } \\
\text { ir atitrūkti nuo } \\
\text { kasdienybès }\end{array}$ & 15 & 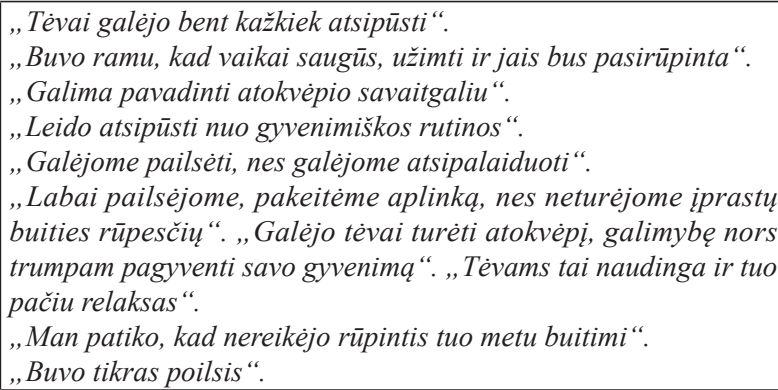 \\
\hline $\begin{array}{l}\text { Tèvų, auginan- } \\
\text { čių negalią tu- } \\
\text { rinčius vaikus, } \\
\text { bendradarbia- } \\
\text { vimo plètojimas }\end{array}$ & 14 & $\begin{array}{l}\text { „, Susipažinau ir pabendravau su tèveliais, auginančiais negalia } \\
\text { turinčius vaikučius“. } \\
\text { „Labiausiai patiko kad buvo sudarytos salygos susitikti, susipažinti, } \\
\text { pabendrauti su kitomis mamytemis “. } \\
\text { „Pasidalinimas naudinga informacija, kitu mamu patirtimi labai } \\
\text { pravertè". } \\
\text { „Bet svarbiausia manau tokiu stovyklu prasmè, pabendrauti ir tè- } \\
\text { vams tarpusavyje, pasidalinti patirtimis“. } \\
\text { „Galejau pabüti su panašaus likimo mamomis“. }\end{array}$ \\
\hline $\begin{array}{l}\text { Socialinès } \\
\text { integracijos } \\
\text { stiprinimas }\end{array}$ & 10 & 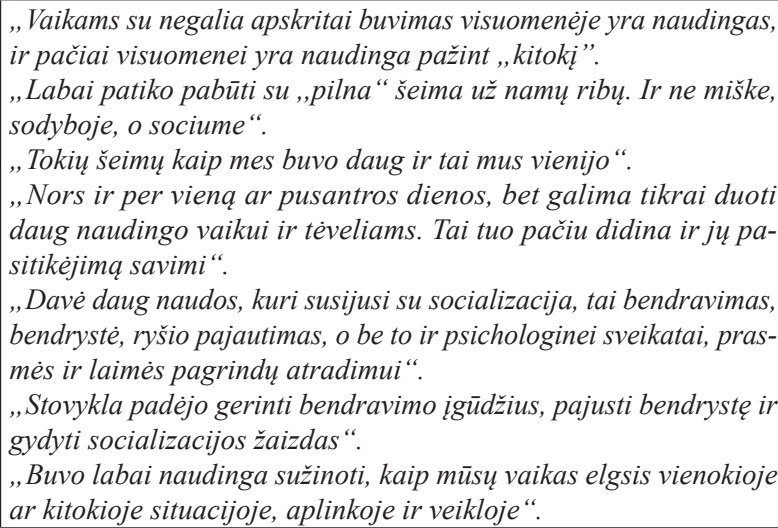 \\
\hline
\end{tabular}

„Tévai galejo bent kažkiek atsipūsti“. „Buvo ramu, kad vaikai saugūs, užimti ir jais bus pasirūpinta“. „Labiausiai patiko, kad buvo sudarytos salygos susitikti, susipažinti, pabendrauti su kitomis mamytemis “. „Bet svarbiausia, manau, tokiu stovyklu prasmé, pabendrauti ir tèvams tarpusavyje, pasidalinti patirtimis “. „, Galèjau pabūti su panašaus likimo mamomis".

Projektas prisidèjo prie socialinès integracijos, negalią turinčių vaikų dalyvavimo socialiniame gyvenime skatinimo. Tẻvų išsakytos mintys leidžia teigti, kad mūsų šalies kultūroje kol kas stokojama dèmesio negalią turintiems asmenims, trūksta veiklos, stiprinančios jų socializaciją. Tèvų atsakymai liudija apie neišspręstas socialinès integracijos problemas Lietuvoje: , Vaikams su negalia apskritai buvimas visuomeneje yra naudingas, ir pačiai visuomenei yra naudinga pažint ,, kitokị”. „Labai patiko pabūti su ,pilna "šeima už namu ribu. Ir ne miške, sodyboje, o sociume". „, Tokiu šeimy kaip mes buvo daug ir tai mus vienijo “. „,Nors ir per viena ar pusantros dienos, bet galima tikrai duoti daug naudingo vaikui ir teveliams. Tai tuo pačiu didina ir ju pasitikejjima savimi “. „,Davé daug naudos, kuri susijusi su socializacija, tai bendravimas, bendrystè, ryšio pajautimas, o be to ir psichologinei sveikatai, prasmès ir laimès pagrindu atradimui “. „, Stovykla padejo gerinti bendravimo igūužius, pajusti bendrystę ir gydyti socializacijos žaizdas".

Tèvai, dalyvavę apklausoje, pateikè keletą siūlymų tobulinti būsimų projektų vaikams, turintiems negalią, kokybę.

Vienas iš siūlymų - ilgesnès trukmès arba nevienkartinès stovyklos: „, Galbūt reikètu daugiau organizuoti apsilankymu sanatorijose ar vasaros stovyklose“. „Stovykla organizuoti ilgesniam laikui“".

Dar vienas siūlymas - svarstyti galimybes organizuoti veiklą, atsižvelgiant ì vaikų negalią ir amžių: ,, Gal ateityje 
reikètu orientuotis $\underline{i}$ vaiku amžiu, nes mano berniukui nebuvo ka veikti su dičkiais “. „, Gal bütu galimybè apjungti negalias turinčius vaikus pagal diagnozes. Mielai lankyčiausi tèvu savitarpio pagalbos grupeje, kuri būtu specializuota (pvz., tevai, auginantys vaikus su lengvu autizmo sutrikimu). „, paskaitas kviesti ne pagal loterija, o klasifikuoti pagal sutrikimus: Dauno sindromas, autizmas, cerebrinis paralyžius, tuomet laikas bus produktyviau išnaudojamas".

Tèvų manymu, mokymai ir konsultacijos taptų dar naudingesni, jei tèvai turetų galimybę iš anksto gauti mokymų medžiagą (prieš seminarus ar edukacines stovyklas): „Galima atsiusti skaidres pasiskaityti prieš seminara, o seminaro metu tik atsakyti i iškilusius klausimus".

Projekto metu tèvams, auginantiems vaikus su negalia, surengti mokymai ir teiktos konsultacijos ịvairiomis temomis: apie pirmąą pagalbą, masažus, higieną, burnos sveikatos priežiūrą, mitybą, tracheostomų, gastrostomų priežiūrą, lytinį brendimą. Tyrimo rezultatai atskleidè ne tik pozityvų šių mokymų vertinimą, bet ir išryškino konsultacijų poreikị ivairiomis kitomis tevvams aktualiomis temomis bei formomis: „Noréčiau daugiau asmeniniu konsultaciju“ “. „Būty ¿̇domu bendravimo su vaiku asmeninè psichologo konsultacija. Socialinio ar kito darbuotojo, gydytojo konsultacija, kokios paslaugos ir lengvatos priklauso pagal vaiko ligos diagnoze“. „, Streso valdymo pratimai ir atsipalaidavimo pratimai labai padètu“. „, Trüko psichologo seminaru tèvams “. „, Šeimos santykiu specialisto patarimai būtu labai naudingi“. ,,Viskas puiku, gal tik trūksta savanoriams korteliu su vardais “. „Pastebejau, kad vaikai bijo agresyviai besielgiančiu vaiku, kažkaip reikètu juos nuo to apsangoti “. „Reikètu turèti slaugytoja, kuri galètu pasirūpinti vaiku, turinčiu tracheostoma (atsiurbti), gastrostoma".

\section{Išvados}

1. Vaikų, turinčių negalią, socialinès integracijos, medicininès, edukacinès ir psichosocialinio pobūdžio pagalbos teisinè bazė sukurta, tačiau trūksta kryptingos priemonių sistemos, leidžiančios negalios paliestoms šeimoms suvokti savo galimybes, palaikyti gerą psichosocialinę sveikatą ir užtikrinti visavertị socialinį dalyvavimą. Negalią turintys vaikai ir jų šeimos dažnai patiria socialinę atskirtị, pasigenda informacinès, konsultacinès pagalbos ịvairiais su negalia susijusiais klausimais.

2. Tèvams, auginantiems negalią turinčius vaikus, reikalingos priemonès, padedančios stiprinti negalios paliestos šeimos socioemocinę sveikatą ir gilinti žinias apie negalią turinčių vaikų priežiūrą ir fizinès sveikatos išsaugojimą. Tyrimo rezultatai atskleide, kad projekte igyvendintos priemonès ir veiklos rūšys, apimančios tėvų mokymą ir konsultavimą vaikų, turinčių negalią, fizinio aktyvumo stiprinimo, sveikatos priežiūros klausimais, edukacines keleto dienų stovyklas, artimujų savitarpio pagalbos grupių organizavimą, tėvams buvo reikalingos ir naudingos. Tèvai ịgijo vaikų su negalia priežiūros naudingų žinių ir ịgūdžių, pagerino savo emocinę sveikatą, sustiprino bendravimą su vaikais ir kitais šeimos nariais, išsiugdẻ socialinio įsitraukimo gebejjimų.

3. Tyrimo rezultatai parodè psichologinę ir socialinę dalyvavimo projekto veikloje naudą. Tèvai turejo galimybę atitrūkti nuo kasdienybès, pailsèti, susipažinti, pabendrauti ir pasidalinti informacija bei patirtimi su kitais tèvais, auginančiais negalią turinčius vaikus. Projekto vykdymas padėjo šeimoms, auginančioms negalią turinčius vaikus, pajusti sutelktumą, bendrystę, ịveikti socializacijos kliūtis, didinti pasitikejjimą savo jègomis.

\section{Literatūra}

1. Lietuvos Respublikos Vyriausybès $2012 \mathrm{~m}$. lapkričio 21 d. nutarimas Nr. 1408 "Dėl nacionalinės neigaliųjų socialinès integracijos 2013-2019 metų programos patvirtinimo". https://e-seimas. 1rs.lt/portal/legalAct/lt/TAD/TAIS.437985?jfwid=-35aaxr582

2. Lietuvos Respublikos Seimo 2003 m. gegužès 20 d. nutarimas Nr. IX-1569 "Dèl Vaiko gerovès valstybès politikos koncepcijos patvirtinimo". https://e-seimas.lrs.lt/portal/legalAct/lt/ TAD/TAIS. 211767

3. Lietuvos Respublikos Seimo 2008 m. birželio 3 d. nutarimas Nr. X-1569 "Dèl Valstybinès šeimos politikos koncepcijos". https:/e-seimas.lrs.lt/portal/legalAct/lt/TAD/TAIS.322152/ AjTTvgkerq

4. Diržytė A., Mikulènaitė L., Kalvaitis A. Autizmo sutrikimų turinčių vaikų situacija ir ịtraukties ị švietimo sistemą galimybės. Vilnius, UPC, 2016.

5. Lietuvos Respublikos lygių galimybių ịstatymas Nr. IX1826, 2003. https://e-seimas.lrs.lt/portal/legalAct/lt/TAD/ TAIS. 222522

6. Lietuvos Respublikos neigaliųų socialinès integracijos įstatymas Nr. I-2044, 1991.

https://e-seimas.1rs.lt/portal/legalAct/lt/TAD/TAIS.2319? jfwid=73odxy8po

7. Lietuvos Respublikos socialinès apsaugos ir darbo ministerija. Statistika, 2018.

https://socmin.lrv.lt/lt/veiklossritys/socialine-integracija/ neigaliuju-socialine-integracija/statistika-2

8. Lietuvos Respublikos specialiojo ugdymo įstatymas Nr. VIII969, 1998 (negalioja).

https://e-seimas.lrs.lt/portal/legalAct/lt/TAD/TAIS.69873

9. Lietuvos Respublikos švietimo įstatymas Nr. I-1489, 1991. https://www.e-tar.lt/portal/lt/legalAct/TAR.9A3AD08EA5D0

10. Lietuvos Respublikos vaiko teisių apsaugos pagrindų įstatymas Nr. I-1234, 1996.

https://e-seimas.lrs.lt/portal/legalAct/lt/TAD/ TAIS.26397? jfwid=73odxy90o 
11. Neigaliųjų ir kitų visuomenès narių nuomonès apklausa, įvertinant Jungtinių Tautų neiggaliụu teisių konvencijos ịgyvendinimo efektyvumą Lietuvoje 2017 m. Neigaliųjų reikalų departamentas.

http://www.ndt.1t/wp-content/uploads/Lietuvosne $\%$ C4\%AFgali\%C5\%B3j\%C5\%B3-draugijosataskaita2017.12.07-GALUTINI.pdf

12. Neigaliujų socialinès integracijos veiklos rezultatų bei Jungtinių Tautų neigaliųjų teisių konvencijos ir jos fakultatyvaus protokolo $2018 \mathrm{~m}$. stebėsenos ataskaita.Neigaliųų reikalų departamentas, 2019.

http://www.ndt.1t/wpcontent/uploads/JT_neigaliuju_teisiu_ konvencijos_stebesenos_ataskaita_GALUTTINE.pdf

\section{NEEDS AND BENEFITS OF MEASURES TO IMPROVE THE PSYCHOSOCIAL HEALTH AND SOCIAL INCLUSION OF CHILDREN WITH DISABILITIES AND THEIR PARENTS} V. Piščalkienė, L. Navickienė

Keywords: disabled children, social inclusion, psychosocial health.

\section{Summary}

Child disability is a challenge for all family members. In Western countries the system of social, medical and educational assistance for disability has been in existence for decades. Although the necessary legal framework is developed in Lithuania, this type of assistance is still shaping its traditions. Counseling and psychosocial support is one of the most effective ways to improve the physical health of parents, relatives and relieve fatigue. The most effective methods for achieving an emotional, physical balance are support groups that involve individuals with similar life challenges.

In 2018 - 2019 the project "Improving the physical and psychosocial health of children with complex disabilities" (funded by the Ministry of Health of the Republic of Lithuania, Public Health Pro- motion Fund) was implemented by the Faculty of Medicine, Kaunas University of Applied Sciences together with Kaunas District Social Services Center. The project was aimed to contribute to the improvement of the physical and emotional health and social inclusion of children with disabilities and their relatives. Project activities included parents' teaching and counseling on enhancement and health care of disabled children, educational camps, organization of parents supporting groups.

The project target group - children with disabilities $(\mathrm{N}=60)$ and their parents, brothers / sisters $(\mathrm{N}=120)$. The age of the children was from 2 to 17 years old. The main disabilities of the children were: autism spectrum disorder, Down syndrome, paralysis, myasthenia, rare genetic diseases. The project was based on the social paradigm "What are the child's health sources?" "How to strengthen them?". In this way, the child's difficulties were solved by focusing on the child's powers and abilities, using not only his or her resources but also the surrounding environment.

The study aimed to reveal parents' views on the need and benefits of the activities and measures implemented in the project for their children with disabilities and for themselves. The study included 54 parents of children with disabilities. To achieve the research objective a survey including closed and open type (qualitative) questions was conducted. The results of the survey revealed a favorable evaluation of all the activities carried out in the project. Parents claim that by participating in the project activities they have acquired useful knowledge in children's oral hygiene, nutrition, first aid, sexual maturation, improved gastrostomy, tracheostomy care skills, learned the basics of massage. Parents also see the psychological and social benefits of participating in the project. They claim to have improved emotional health and communication skills with children and other family members.

Correspondence to: viktorija.piscalkiene@go.kauko.lt

Gauta 2019-11-10 